\title{
家㷵藏絲色素の化學的研究（第一報）
}

黄䒽色素 Xanthophyll に就て

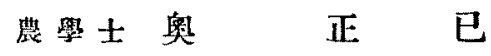

(昭和四年十二月三日受理)

緒 論

䔕絲は品種の相違によりてさまさま異つた色を呈しその色素の含量は微量では

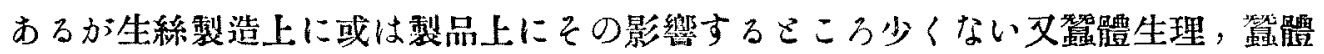
遺傳學の方面から考へても甚だ重要視さるべものである從來この色素類の研究 が等閑に附せられて来たのは一にその含量が微量にして之を純粹に分離する方法 が考究されなかつた第であり從つて今日に至るまでその色素の本態に就て䍱り精 確なる知識を得るここが出桃ない有樣である

蔝絲の黄色色素に關する從隶の文献を見るにDubois ${ }^{(1)}$ 氏ば生絲の黄色色素さ して五程の色素を分離し Carotin に類似の物質であると推論した Levrat 及び

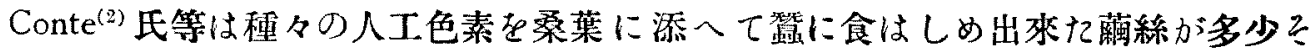
れこ同じ色に着色することる觀察し以つて生絲の黄及綠の色素は夫タ食慨てる桑 葉中の黃色色素並びに葉綠素に起因するるのであるこ結論した中根氏 ${ }^{(3)}$ は支那金 黃種の黄色色素に就て研究し色素の單なる浸出液に就てそれか; Chlorophyll の反

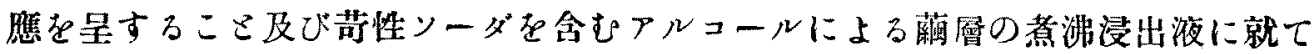
Carotin の反應を檢出して事を報し本塚氏(4) は藏の顯色法に就て菻をアンモニア

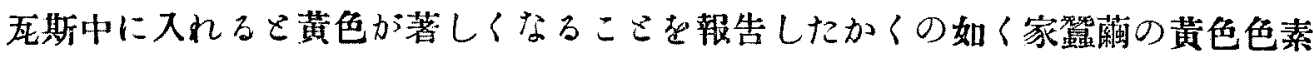
に關する從承の研究は何几るその色素の浸出液又は不綂なる物質に就て僅かの定 性反應る試みたる結果よりの推測てるにすざぬ

芸に於て私は藏の色素類の研究に志し先づ黄色色素に就てその性質本性る明ら

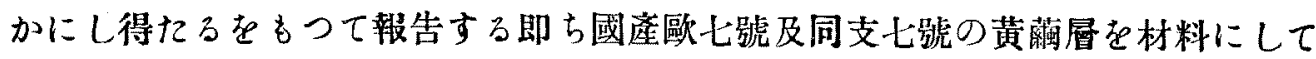
加壓の下に短時間アルコールにて色素导抽出し Carotinoid の Xanthophyll fraction がら該色素を結晶狀態に純粹分離し得てこれの吸收バンド，分子量，元素組成及 び其他の定性反應を檢したる結果 Xanthophyllなるここね確め且つ歐七號も支七 號もその黄色色素の大部分は同しくXanthophyllなるここを望證した 


\section{賽 驗之部}

I. 歐七號藏の黄色色素の分離調製

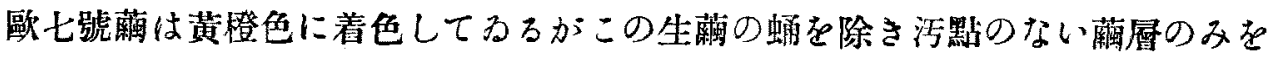
細片に刻んでェーテルにて浸出し色素の單離に妨げさなる侅質物の大部分を除き

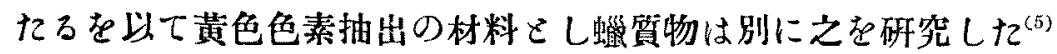

上記の逦層 $500 \mathrm{~g}$. を $6 \mathrm{~L}$. のビーカーに詰め之れに $80 \%$ のアルコール $5 \mathrm{~L}$. を 加へAutoclaveに入れて一或厴の下に 30 分間蒸者する得たら褐赤色のアルコール

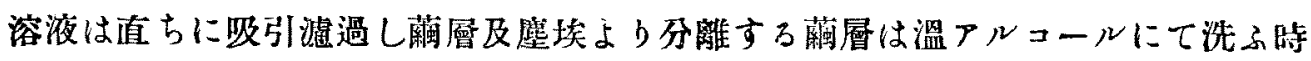
は單に一包の加塺浸出によつて橫色色素は殆ご大部分浸出し得るアルコール溶液

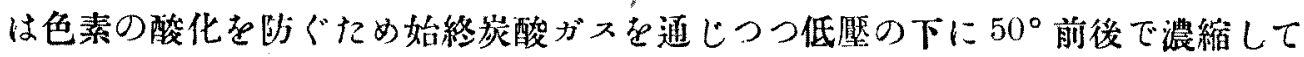
約 600 c.c. こし之を 1.5 L.の分液膤斗にうつして約 400 c.c.のエーテルを共に振る

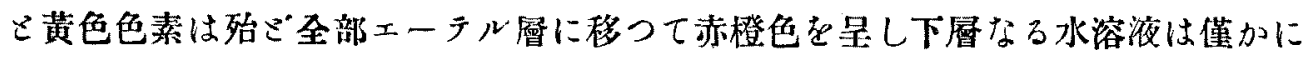

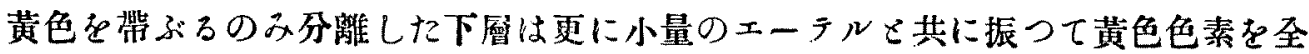
くェーラルに取りェーラル溶㴕は凡て合し $50 \mathrm{c.c}$. の水で二回洗ひ水溶性フラボ ン類色素を除去する（水溶液はアルカリの添加により著しく黄色を是する）次に 分液漏斗に殘れるエーテル溶液に苗性加里饱和のメチールナルコール20 c.c. を加

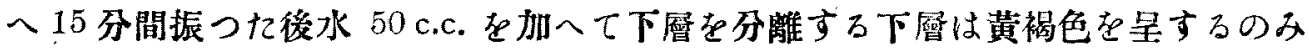
で綠色走呈せす從つて葉緑菜の存在を認むるここ能はすエーテル溶液はアルカリ 性の無くなるまで數包水にて沜ひ最後に無水硫酸ソーダで㧤水して後低厴低溫の 下に炭酸ガスを通じつつ蒸發乾固して赤色塊狀の殘㳯を得るこの中には Carotin， Xanthophyll 等の Carotinoids が存在するものこ思推して之を石油エーラル（涨點 $\left.40^{\circ} \sim 60^{\circ}\right) 650$ c.c. こ 300 c.c.の $85 \%$ メチルルコールさ共に分液漏斗に溶加

し移してょく振盪したる後赫色を呈する下畨のメチルアルコール溶液 (Xanthophyll fraction) を奇離し次に $90 \%$ メルアルコール 100 c.c. 最後に $92 \%$ メチル

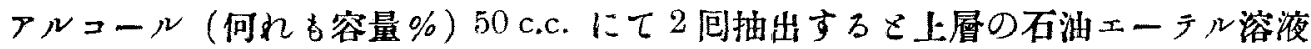
(Carotin fraction) の鱼色は殆ご全部メチルアルコールに移るこつに於てメチルア ルコール溶液は凡て之を合して分液漏斗に入れ 300 c.c. のエーテルを加へ更にメ チルアルコール飞同容樍の水を加ふれば色素は凡てェーテル層にうつるから下層

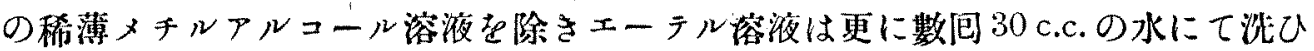
てる後低溫低壓の下に炭酸ガスを通しつつ濃縮して約 50 c.c.さなし此際もし分 
䧿する水あらば除きエーテル溶液は最後に結晶皿に移して炭酸がスを吹边みつ〉 溫浴上にてェーテルを追出す此の際エーラルの臭氣以外に極めて刺戟性の violetlike の臭枨势發散す（之は酸化の過程にある黄色色素に上るもの巳想像する）加 くて得てる赤紅色の葵發残㵏堂沸メチルアルコールから再結晶する時は暫時に

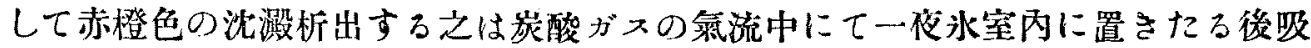

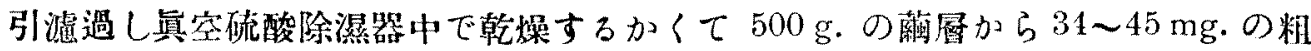

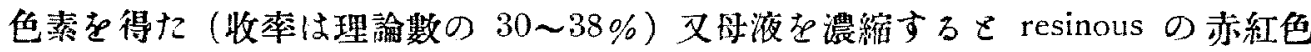
非絬晶怪の残涬在得る

粗色素は一回の再結晶のみではな汪Wax や無晶性の色素を含むから之を30〜 40 c.c. の石油エーラルにて惹沸して是等の不純物を溶し去り殘りを更に者沸メキ ルァルコールから再結するて差麗なる長方形板狀の絬品が析出する(第一圖参照) 結晶店顯微鏡下に检するに杜狀の兩端並びに周圍處々に刻みありて Xanthophyll の結晶に酷似する結晶は舟液と共にメチルアルコールを容れたる密閉器に入れて

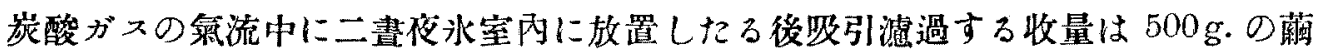
層から約 $20 \mathrm{mg}$.であつた之純色素として前記の粗色素こ區別する

II. 黄色色素の性質

（1）色 澤:一 粗色素は乾燥粉末にするさ赤褐色高呈するが純色素の結 晶は透過光線に上り黄色乃至橙色の多色性を有し反射光線に上りて紫赫色を呈し 光輝を有す無臭にして溶媒內に suspend する時は steel blue の反射色を示す

（2）溶媒：一 純色素にWax 走含むここ多ければ石油ェーラルに溶け 易くなるが然らざる場合は殆ど全く溶けない泠アルコールには殆ご溶け好が煮沸 アルコールには上く溶ける冷二硫化炭素, ぶンビンには溶け難いがエーテル，ア セトン，ク口ロホルムには冷溫で比較的よく溶ける但し二硫化炭素，ク口ロホル 么溶液は赫褐色呈しその他の溶液は黄橙色乃至黃色走呈す石油エーテル溶液か

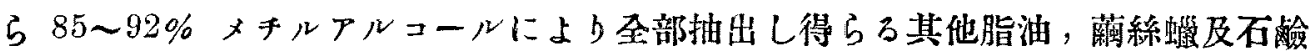
等に溶けて黄色を呈すメチルアルコールより再結すると一分子のアルコールを結 晶溶媒さして有す

\begin{tabular}{|c|c|c|}
\hline 物貿 (mg.) & 減量 (mg.) $\left(\begin{array}{l}56^{\circ} \text { て } 2 \text { 時間 } \mathrm{P}_{2} \mathrm{O}_{5} \\
\text { ので真空乾燥 }\end{array}\right)$ & $\% \mathrm{CH}_{3} \mathrm{OHI}$ \\
\hline 8.620 & 0.472 & 5.47 \\
\hline
\end{tabular}


又上記の溶媒の色素溶液を明處に放置する時は漱次褪色漂白する

(3) 融 點: 一 粗色素は $168^{\circ}$ 頃から收縮し $171^{\circ}$ - $173^{\circ}$ でをける純色素 は $174^{\circ} \sim 175^{\circ}$ (不訂正) で融けて紅色透明となるこの融點は睤てWillstätter 氏の 得㲸る Plant origin の Xanthophyll に一致する

(4) 元素組成：一 峌素を含まず純色素の微量元素分析の結果は次の通りで ある

\begin{tabular}{|c|c|c|c|c|}
\hline 物貿 (mg.) & $\mathrm{CO}_{2}$ (mg.) & $\mathrm{H}_{2} \mathrm{O}$ (mg.) & $\mathrm{C} \%$ & $11 \%$ \\
\hline 3.262 & 10.080 & 2.953 & 84.26 & 10.13 \\
\hline 3.117 & 9.646 & 2.884 & 84.38 & 10.35 \\
\hline
\end{tabular}

即ち Xanthophyll によく一致する

（5）分子量:一 純色素の分子量走 K. Rast 氏法によつて測定した

\begin{tabular}{|c|c|c|c|}
\hline 樟䐉 (g.) & 物筫（g.） & 融㪇降下 $\left({ }^{\circ} \mathrm{C}\right)$ & 分子量 \\
\hline 0.1327 & 0.0110 & 6.0 & 552.6 \\
\hline
\end{tabular}

師ち Xanthophyll の分子量によく一致する

（6）吸收バンド:- 粗色素の吸收ベンド測定の結果は炏の通りである (第二圖及第三圖參照)

\begin{tabular}{|c|c|}
\hline Solvent...............Alcohol & $\mathrm{CS}_{2}$ \\
\hline Thickness.$\cdots \ldots \ldots \ldots 28 \mathrm{~mm}$ & $20 \mathrm{~mm}$ \\
\hline Band $I \ldots \ldots \ldots \ldots 487 \sim 472(\mu \mu)$ & $516 \sim 500(\mu+1)$ \\
\hline Band $11 \ldots \ldots \ldots+454 \sim 439$ (") & $480 \sim 468(\prime \prime)$ \\
\hline Band III........421 414 (" ) & $447 \sim$ \\
\hline
\end{tabular}

之を Willstätter 及び Stoll 氏等が Xanthophyll に就て得たる結果 ${ }^{(6)}$ に比較す るによく一致する在知る

（７） Iodide：一 純色素のエーテル溶液に沃素を加へると直に黑紫色の結晶

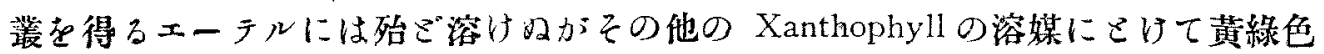
の液をなる一定の融點を有せず

(8) $\mathrm{CaCO}_{3}$ に對する四着性:燥した沈降性 $\mathrm{CaCO}_{2}$ を一方毛細管に引ける試驗管につめて粗色素の石油エーテ ル又は二硫化炭素溶液を通過さす時は色基は凡て炭酸石灰の上牛層に於て均一に 四着されて之を上記の溶媒に上つて洗ふも容易に溶かし出される又純色素に就て。 
同樣に筫驗するに粗色素に比して炭酸石灰に對する Affinity 弱くその吸着層は 潮次下半曆に移行して終には溶け出るここを認めた而して一度四着されたる該色 素はアルコールを含む上記の溶媒によつて速かに溶かし出される

（9）呈色反應:一 粗色素，純色素共にCarotinoids の通有反照及び Vitamin A の是色反應の一部支 positive に與へる

(a) $\mathrm{Fe}_{2} \mathrm{Cl}_{6}$ :一 色素の極小量を無色のォリーブ油に溶かし之れに $\mathrm{Fe}_{2} \mathrm{Cl}_{6}$ の 結晶細片を投入すると暫時にして美しい綠色を呈す

(b) 酸性白土：一 豫め乾燥した酸性白土を色素のベンゼン溶液に加ふれば 白士は美麗なる綠绝を呈す但し白士の代りにFuller’s earthを用ふればVitamin A と翼りて呈色せず

(c) 硫酸及其他の酸類:一 色素の結晶に漂硫酸を加へると濃青色を呈して 溶け水で稀むると緑色の沈澱を生ず濃暨酸を含む溫エチルアルコールに溶けて 初め綠色を呈するが㣪に青色に築万濃硝酸，溫水醋酸に會ふと無色に溶ける其 他蟻酸に溶けて綠色を呈す

(d) $\mathrm{SbCl}_{3}, \mathrm{ZnCl}_{2}$, etc., :一 該色素に $\mathrm{SbCl}_{3}$ のクロロホルム溶液を加へるを 美しい青藍色を呈す此の呈色は比較的荌定である又色素のべンゼン溶液に

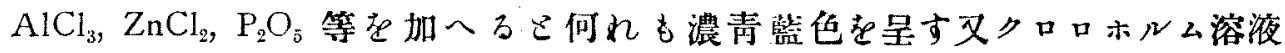

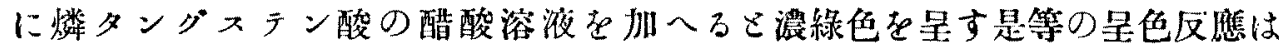
Vitamin A に於て positive である

(10）膠質溶液:一 色素のアルコール濃厚溶液を低壓にて少し溫ためなが 涱縮して數 c.c. にし之れに數倍容の水走加へると黄橙色の膠質溶液が得らる

以上の如く其性質を通覽するに歐七號藏絲から分離して黄色色素は Willstätter 氏等加分碓した Plant origin の Xanthophyll によく一致するを知る

\section{III. 黃藏絲中の Xanthophy1l の定量}

以上の貿驗によつて歐七號桠絲の黄色色素の殆ぞ全部が Xanthophyll なること

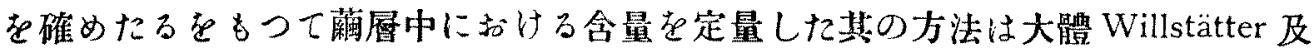

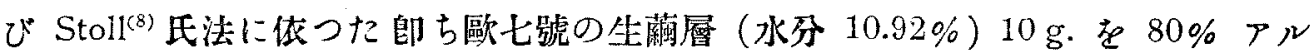

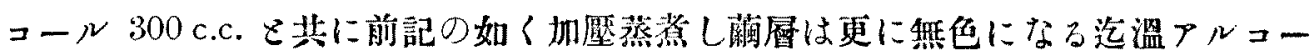
ルで湤ひたる後得たる 800 c.c. 俆の黄褐色のアルコール溶液は前同榡に濃縮して 小量のアセトンと共に 400 c.c. の癹液漏斗に移し 200 c.c. のエーテルを加へ静加 
に廻轉しつ〉抽出を行ふ下啳の水溶液を除去しなほ $1 \%$ 炭酸ンーダ 20 c.c. にて

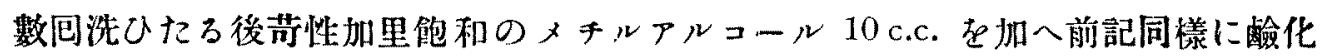

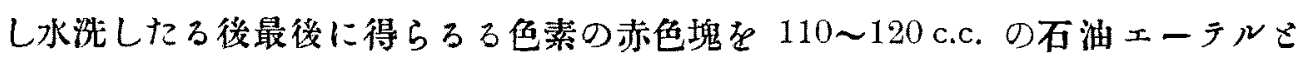

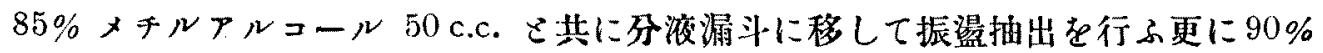

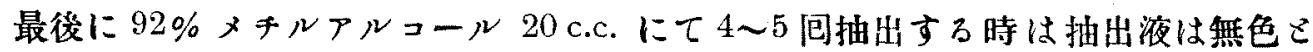
なら石油エーテル溶液（Carotin fraction）は僅かに黄色を星するのみ之によつて 見れば蕃の黄色色素は殆ご全部が Xanthophyll であつて Carotin の存在疑はるか くて得たるメチルアルコール抽出液は全部合して 30 c.c.のエーラルを加へなほ メチルアルコールを同容の水を加ふれば Xanthophyll は凡てェーテルに移る數国

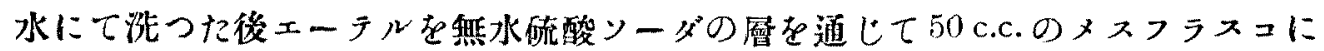
泩さ 50 c.c. に滿す落に得たる Xanthophyll のェーテル溶液を $0.2 \%, \mathrm{~K}_{2} \mathrm{Cr}_{2} \mathrm{O}_{7}$ の 水溶液を標準にして比色定量にかけた其結果は炏の通りである

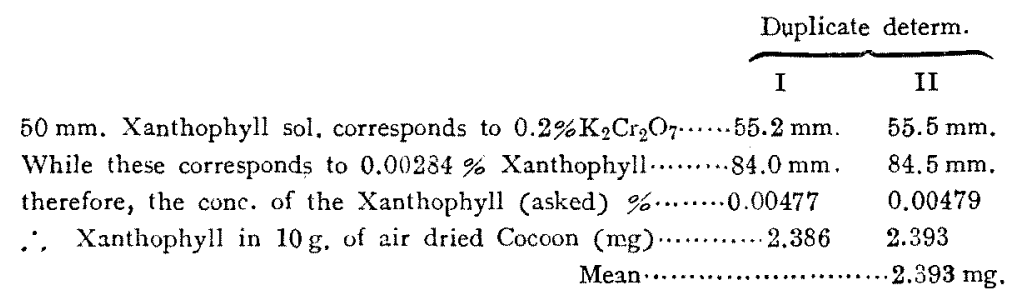

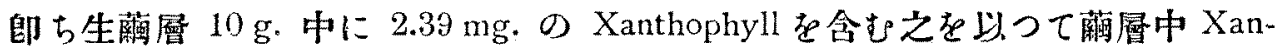
thophyll の含量の理論數とした

IV. 支七號㡀 (金黄) 黄色色素

支七號菊は全く黄金色を呈しその色澤によつて區七號蕨から容易に區別し得る

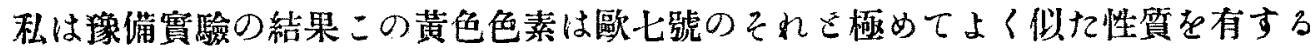

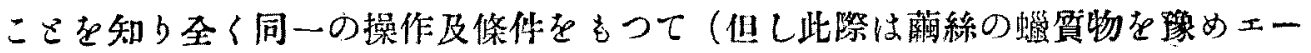
テルにて除か2）生藏屡 $600 \mathrm{~g}$. 加ら $80 \mathrm{mg}$. の粗色素を得扢之歐七號藏の場合 よりる多量のWax そ無晶性黄色色素さを含んで居るから更に石油エーラルにて 募沸し最後にメチルアルコールから再結晶して約 $18 \mathrm{mg}$. の純色素を得た其結晶 形, 色澤, 呈色反䈍, アルコール溶液の吸收バンドの位置（第四圖參照）等は凡 て歐七號蔽上り得たるXanthophyll に一致する且つ

融點:一 純色素は $174^{\circ} \sim 175^{\circ}$ (不訂正)で融け歐七號藏より得たる Xanthophyll を混してをる融點降下せず 
元素組成:一 微量元素分析の站果は次の通りである

\begin{tabular}{|c|c|c|c|c|}
\hline 物質 (mg) & $\mathrm{CO}_{2}$ (mg.) & $\mathrm{H}_{2} \mathrm{O}(\mathrm{mg})$ & $\mathrm{C} \%$ & $\mathrm{H} \%$ \\
\hline 3.215 & 9.915 & 2.914 & 84.10 & 10.14 \\
\hline 3.168 & 9.762 & 2.852 & 84.03 & 10.07 \\
\hline
\end{tabular}

分子量:-

\begin{tabular}{|c|c|c|c|}
\hline 橦㨫 (g.) & 物留 (g.) & 融㓵除下 $\left({ }^{\circ} \mathrm{C}\right)$ & 分子量 \\
\hline 0.1534 & 0.0128 & $6^{\circ} \mathrm{C}$ & 556.3 \\
\hline
\end{tabular}

而して生蒴曆中に含まるっXanthophyll の量は歐七號の場合を同精に定量した 結果 $10 \mathrm{~g}$. の風乾䔪曆 (水分 $10.65 \%$ ) 中に $2.219 \mathrm{mg}$. の Xanthophyll t含み歐 七號の場合より約 7\% 少いことを知つた

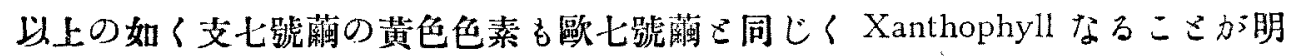
らかである

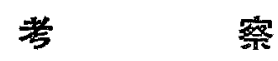

本研究の材料にした黄藏の黄色色素は蒱層を單に色素の溶媒にて冷浸入は湴溜

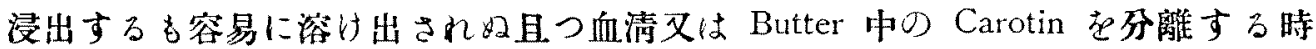
の如く Plaster of Paris ミアルコール及石油エーテルとの混合溶液をもつて振盪

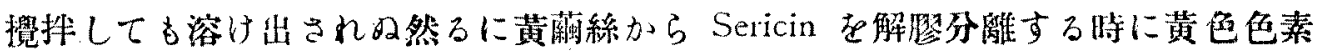

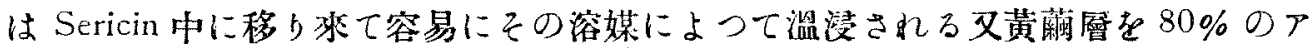
ルコールに浸して一氣釐の加㻺の下に短時間加熱蒸煮するこ Sericinは少しる溶 けないで色素及Wax如名圣部溶かし出されるもし $95 \%$ アルールを用ふれば Sericin の Coagulation を助長して色素注餘り溶出されぬ是等の點上り考へて蔽の 黄色色素 Xanthophyll は恰も Carotin が Serum albumin に溶けるが如くSericin こ physico-chemicallyに結合してるるものさ考へらる

Tswett ${ }^{(9 j}$ 氏によれば Xanthophyll の二硫化炭素刃は石油エーラル溶液を炭酸石 灰の㸴占通すをXanthophyll は凡て吸着されて解離し嚾い吸着化合物をつくり且 この吸着層が數層に分れるここょり Xanthophyll に數種の Isomer が存在するこ と施めて然るに最近 Schertz(10) 氏の報告によれば Tswett 氏の假定した數種の Isomerは實は種々つ酸化の過程にあるXanthophyll なる事を指摘して純粹の Xanthophyll は炭酸石灰によつて殆ざ四着されず只 Carotinよりも遲く通過する 
ものなる事を明らかにして Carotin と Xanthopyll とを區別するにはTswett 氏法 は不適當にして Willstätter 及び Stoll 氏等のメチルナルコールによる分㓢浸出法 をもつて優れりこした既述の如く私も粗色素，純色素に就て炭酸石灰に對する四 着性を究め且つ色素溶液を酸化をうける條件に永く置けば置く程この吸着性か强 くなることを觀察した之等の事實上りすれば黄藏の黄色色素中には種々の酸化の 過程にあるXanthophyll を含んで居るすのこ思惟さる而して時日の經過と共に黃 㡀色の裉せて行き又乾藏作業によつて黄色調の褪せる事實は矢張り Xanthophyll の部分的酸化漂白によるものであらう

すでにして黄藏の異色色素は Xanthophyll なるこをが明らかになりてる以上こ の Originは何處に求むべかは興咮する問题でする私は新鮮なる桑葉を材料に してアセトン及エーテルを以つて綠葉の色素を定量的に抽出し常法によつて Flavone, Chlorophyll等を除去したる後黄色色素の石油エーラル溶液能述の方法 でメチルアルニールにて浸出し比色によつて $10 \mathrm{~g}$. の䄧鮮桑葉中に約 $1.27 \mathrm{mg} .0$ Xanthophyll と $1.01 \mathrm{mg} . の$ Carotin を定量した勿論この含量は材料探取の種タ の條件によつて翼るも桑葉中に明らかに Xanthophyll が存在する以上他の動物體

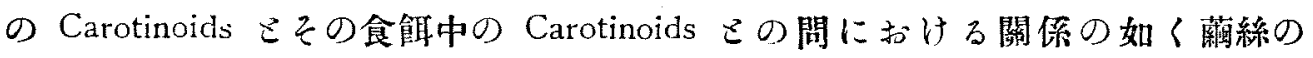
Xanthophyll も其の Origin 在桑葉に發するもの已教察さる（但し是等の事實に關 しては更に詳細に研究中でおる)

\section{總括}

（1）黃菊國産歐七號及支七號の黄色色素に就て硎究し门

（2）歐七號藏を材料にしてその黄色色素を純粹に結晶分傩してそれの諾性質 をしらへて Xanthophyll なる事志確めれ

（3）支七號蔽の黄色色素む同樣に結晶分離して歐七號藏こ四しくXanthophyll なる事を確めた

（4）雨黄藏種の桠係中におけるXanthophyll の含量を定量した結果歐七號は $10 \mathrm{~g}$. の風乾袖層中 $2.39 \mathrm{mg}$. 支七號は $2.21 \mathrm{mg}$. であつた

(5) 蕨絲中つ Xanthophyll は Sericin 飞物理化學的に結合してるるここ且つ 種々の酸化の過程にあるXanthophyll を含むこと並びに桑葉中のXanthophyllに その源を仰ぐものなるこをを考察した 


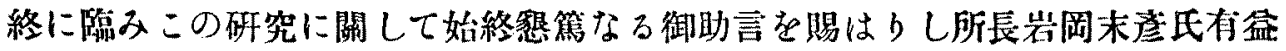
なる御助言を賜はりし恩師鈴木文助博士，柴田雄次博士及び吸收バンド測定の勞 を晹はりし京大農學部霄田耕作氏，徽量元秦分析の勞を睗はり小出又雄氏等に對 して深甚の謝意を表すなほ本研筧資料さして多量の藏曆を御惠興下されし筥事 所長大城鎮氏に深く感謝する

\section{（昭和四年十二月 郡是製係株式會社研究所にて）}

寫 真 說 明

第一圖： 黄蔽色素 Xanthophyll (メチルアルコール上り再結 $\times 120)$

第二圖： 歐七號蔽 Xanthophyll の二硫化宸素溶液の吸收バンド

第三圖："フルコール溶液＂

第四圆： 支七號藏 Xanthophyll のアルコール溶液の吸收バンド

\section{引用文 献}

(1) Dubois: Compt. rend. 3, 802 (1889).

(2) Levrat \& Conte: Journ. Soc. Chem. Ind., 2, 172.

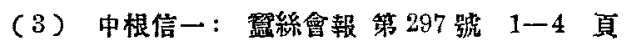

" I" 第 298 號 17-27"

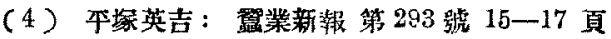

（5）奥 正已：日本農繁化學會䛱，5，344-351.

(6) Palmer: Carotinoids and Related Pigments, 228, (1922).

(7) Tswett: Ber. botan. Ges., 24, 384-393.

Palmer: Loc. cit. 226-229.

(8) Palmer: Loc. cit. 253, 259, 260.

Shertz: Plant Physiol., 3, 211 (1928).

(9) (8) に同し

(10) Shertz: Plant Physiol. 4, 337. (1929). 
第一圖

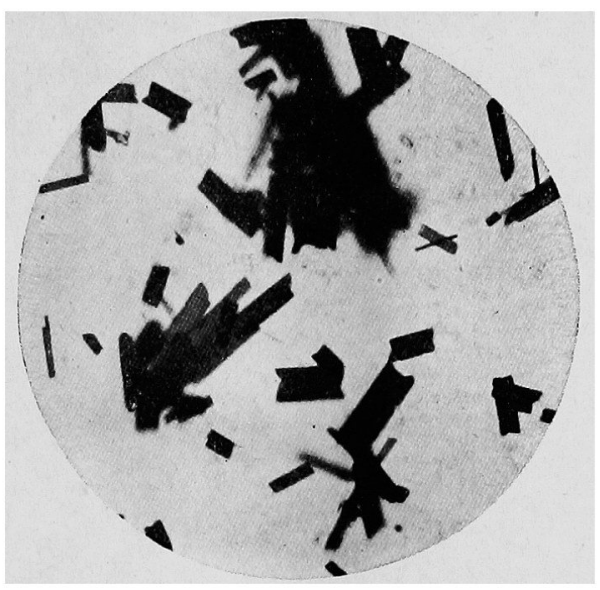

第二 圖

第二圖

第三 圖

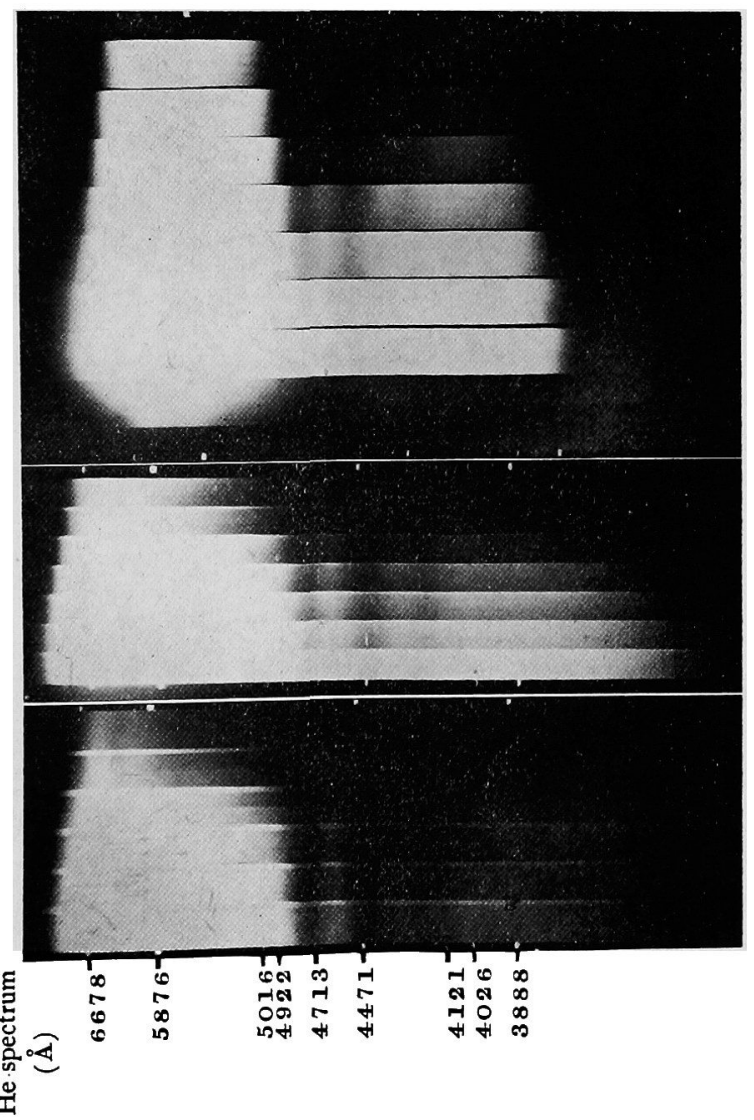

